ОРГАНІЗАЦІЯ КВАЗІПРОФЕСІЙНОЇ ДІЯЛЬНОСТІ

МАЙБУТНІХ ВИХОВАТЕЛІВ ОБДАРОВАНИХ ДІТЕЙ НА ПРАКТИЧНИХ ЗАНЯТТЯХ ІЗ ПЕДАГОГІЧНИХ ДИСЦИПЛІН

\title{
ORGANIZATION OF QUASI-PROFESSIONAL ACTIVITY OF FUTURE EDUCATORS OF GIFTED CHILDREN IN PRACTICAL CLASSES ON PEDAGOGICAL DISCIPLINES
}

Стаття присвячена актуальній проблемі підготовки майбутніх вихователів закладів дошкільної освіти до розвитку обдарованості дітей як окремого напряму професійної педагогіки. Обірунтовано необхінність набуття студентами комплексу якостей і навичок, необхідних для виявлення та розвитку обдарованості дітей. Представлено авторське визначення поняття «підготовка майбутніх вихователів дошкільної освіти до роботи з обдарованими дітьми». Показано значення включення здобувачів вищої освіти у квазіпрофесійну діяльність у контексті їх підготовки до роботи з обдарованими дітьми, у процесі якої створюються умови для набуття ними спеціальної компетентності. Встановлено, що вироблення практичних навичок і поглиблення профресійних якостей студентів на основі засвоєних науково-методичних засад обдарованості $\epsilon$ обов'язковим елементом спеціальноі компетентності майбутніх вихователів обдарованих дітей. Показано значення квазіпрофесійної діяльності загалом $і$ ділових ігор зокрема під час підготовки майбутніх учителів до розвитку обдарованості дітей. Розкрито освітній потенціал практичних занять із педагогічних дисциплін у процесі підготовки майбутніх вихователів обдарованих дітей. Зазначено організаційно-методичні особливості проведення практичних занять. Презеновано авторську структуру практичного заняття й алгоритм, який включає методи навчання $і$ види роботи студентів на різних етапах підготовки та проведення такої фрорми навчання в закладі вищої освіти. Зроблено акцент на підготовчій роботі студентів до практичного заняття, від якості якої залежать результати їхньої навчально-пізнавальної діяльності. Представлено різні види самостійних творчих завдань, які студенти виконують як під час підготовки, так і безпосередньо на практичному занятті. Велике значення надається діловим іграм, інноваційним методам навчання, фрілософрським вправам, які сприяють розвитку профресійних якостей майбутніх педагогів обдарованих дітей. Ключові слова: обдарованість, обдарована дитина, підготовка майбутніх вихователів до роботи з обдарованими дітьми, квазі- профресійна діяльність, практичне заняття, ділова гра.

The importance of preparing future educators of institutions is substantiated pre-school education to the development of giftedness of children as a separate direction professional pedagogy. The arguments according to the need of the development of requirements and complex of qualities and skills for identifying and developing of children's giftedness by the future teachers, starting with teachers of preschool education institutions, are given. The author defines the concept of "preparation future educators of pre-school education to work with gifted children". The value of inclusion of higher education applicants in quasiprofessional is shown activities in the context of their preparation for work with gifted children, during which conditions for obtaining special competence are created. Installed that development of practical skills and deepening of professional qualities of students on the basis of the learned scientific and methodological principles of giftedness is obligatory an element of the special competence of future educators of gifted children. Different types of independent creative tasks are presented students perform both during training, and directly on a practical basis occupation. The significance of quasi-professional activity in general and business games in particular during the preparing the future teachers for the development of children's giftedness is revealed.

The educational potential of practical classes on pedagogical disciplines in the process is revealed the training of future educators of gifted children. The organizational-methodical features of conducting practical classes. Presented is author's the structure of a practical class and an algorithm that includes teaching methods and types work of students at different stages of preparation and conducting of such form of training in a higher education institution. The emphasis is on the students' preparatory work practical lessons, the quality of which depends on the results of their training-cognitive activity. Of great importance is business games, innovative teaching methods, philosophical exercises that promote the development of professional qualities of future educators gifted children.

Key words: talent, gifted child, preparation of future educators to work with gifted children, quasi-professional activities, practice session. педагогічного університету

імені Михайла Коцюбинського фресійно-педагогічної діяльності в умовах ресрормування системи освіти. Майбутні педагоги мають усвідомити «професійну аксіому», що в дитячому колективі серед своїх вихованців вони фрактично не матимуть жодної «типової дитини», яка б перебувала на середньому рівні розвитку й відповідала узагальненому психолого-педагогічному портрету дошкільника / молодшого школяра. Реалії освітньої практики показують, що досить велика частка дітей 
за багатьма показниками соціального, психічного, інтелектуального та фрізичного розвитку має відхилення від умовної вікової норми в бік зменшення чи збільшення. Однією з категорій дітей, розвиток яких не відповідає «стандарту нормальності», є талановиті й обдаровані особистості.

Відповідно до цього, необхідно усунути традиційну орієнтованість професійно-педагогічної підготовки в закладах вищої освіти на вироблення у студентів готовності до організації освітнього процесу загалом, роботи з так званою «абстрактною дитиною» / «середньою особистістю». Варто відкоригувати зміст освітніх програм, заклавши в них теоретично-методичний контент для фрормування в майбутніх вихователів / учителів здатності бачити в кожній дитині неповторну особистість і адекватно сприймати «нетиповість», для засвоєння ними системи спеціальних психологопедагогічних знань і розвитку вміння виявляти індивідуальні особливості й потреби вихованця, створювати сприятливу траєкторію для його особистісного становлення та самореалізації.

щоби не втратити сенситивні періоди для розгортання потенціалів обдарованих дітей, необхідно здійснювати «психолого-педагогічну селекцію» та виявляти прояви обдарованості з раннього віку. Тому відповідні зміни до освітніх програм, пов'язані 3 формуванням готовності до роботи 3 обдарованими дітьми, необхідно ввести, починаючи 3 підготовки майбутніх вихователів закладів дошкільної освіти.

3 огляду на це, окремим напрямом професійної педагогіки вважаємо розроблення і впровадження системи підготовки майбутніх фрахівців психологопедагогічного профрілю до роботи зі здібними й обдарованими дітьми.

Аналіз останніх досліджень і публікацій. Апелювання до пострадянського наукового дискурсу з підготовки майбутніх фрахівців психологопедагогічного профрілю до різних напрямів професійної діяльності дозволило зробити декілька важливих узагальнень.

По-перше, констатуємо, що започатковані експериментальні розвідки, присвячені окремим аспектам фрормування педагога обдарованих дітей, авторами яких є українські (О. Антонова, О. Ващук, В. Демченко, Ю. Клименюк, Л. Корецька, Д. Корольов, Л. Мерва, О. Петрович, Л. Радзіховска, Р. Семенова, Г. Тригубець, В. Ушмарова, М. Федоров, М. Шемуда, О. Черншов та ін.), білоруські (Є. Алехнович, Я. Коломінский, Є. Панько, Т. Поздєєва, Н. Старжинська, О. Чеснокова й ін.), латвійські (Р. Бебре, М. Віднере, І. Жогла, Т. Коке, Ю. Стабиниш, С. Тубеле й ін.), російські (С. Маркова, Л. Радзіховська, Г. Тарасова, І. Ушатікова, В. Юркевич та ін.) учені.

Хоча такі теоретичні узагальнення й методичні розробки спрямовані передусім на підготовку май- бутніх учителів до роботи з учнями різного віку під час вивчення окремих предметів, низка загальних положень може бути реалізована у процесі формування готовності до роботи 3 обдарованими дітьми різних вікових груп у всіх категорій фрахівців психолого-педагогічного профілю. Так, І. Ушатікова [15] визначила перелік якісних характеристик педагога обдарованих дітей, набуття яких, на наше переконання, є також обов'язковим для майбутніх вихователів закладів дошкільної освіти.

По-друге, є праці науковців (Л. Артемова, Г. Бєленька, О. Богініч, А. Богуш, Н. Гавриш, Л. Зданевич, О. Кононко, К. Крутій, Н. Лисенко, В. Майборода, М. Машовець, М. Олійник, Т. Поніманська, О. Проскура, І. Рогальська-Яблонська, Т. Танько й ін.), присвячені професійному розвитку майбутніх фрахівців дошкільної освіти. Автори обґрунтовують умови та пропонують інноваційні методики формування якостей, необхідних як кожному сучасному педагогу, так і вихователю обдарованих дітей. Запровадження інновацій у підготовці майбутніх вихователів закладів дошкільної освіти в сучасній вищій школі сприятиме якісному покращенню підготовленості студентів до професійної діяльності загалом і до роботи з обдарованими дітьми зокрема. Провідні вчені в галузі професійно-педагогічної освіти майбутніх дошкільних педагогів [1] суттєво змінюють тактику організації освітнього процесу у ЗВО, реалізація якої також сприятиме набуттю студентами компетентностей, необхідних для ідентифікації проявів обдарованості в дошкільників, і створенню умов для розгортання потенціалів талановитих дітей.

По-третє, виявлено наукові розробки, у яких дослідницька увага зосереджена на вивченні окремих аспектів підготовки майбутніх фрахівців дошкільної освіти до організації різних напрямів профресійної діяльності, спрямованої на творчий розвиток дітей: музично-педагогічної діяльності (Р. Савченко); з розвитку художніх здібностей (Г. Борин); з фрормування художніх і конструктивних умінь (Н. Голота); із включення в художньоестетичну діяльність (Н. Колесник); 3 розвитку творчості на заняттях із художньої праці (Т. Коломієць), засобами авторської казки (М. Замелюк), художньо-естетичного середовища (О. Дронова), театрально-мовленнєвої (Н. Сиротич) і образотворчої діяльності (К. Ющенко) тощо. Так, за твердженням Р. Савченко [14], серед завдань вихователів закладів дошкільної освіти важливим $€$ розвиток музичних здібностей дітей, високій рівень сфрормованості можна вважати проявом обдарованості. Тому актуалізується проблема фрормування професійної, зокрема музично-педагогічної компетентності фрахівців сучасної системи дошкільної освіти - вихователів і музичних керівників дошкільних навчальних закладів. 
По-четверте, проведено окремі дослідження, метою яких $є$ обґрунтування теоретико-методичних засад підготовки до роботи з розвитку обдарованості дітей дошкільного віку магістрів дошкільної освіти (Л. Руденко) і сімейних вихователів (О. Грисюк); до розвитку професійно-творчого потенціалу майбутніх вихователів ЗДО, високий рівень якого $€$ однією з умов успішної організації роботи з обдарованими дітьми (О. Листопад) тощо. Зокрема, Л. Руденко [13] наголошує на необхідності підготовки магістрів дошкільної освіти до розвитку дитячих обдарувань, розглядаючи її як невід'ємну складову частину їхньої професійної підготовки.

Оцінюючи позитивно названі тенденції, водночас зазначимо, що такі теоретико-методичні напрацювання ще не офрормилися в цілісний напрям педагогічної освіти та лише перманентно запроваджуються у практику вищої школи. 3 огляду на це, проблема підготовки майбутніх вихователів закладів дошкільної освіти до роботи з дітьми із проявами різних видів обдарованості потребує системного теоретичного розроблення та впровадження у практику всіх закладів вищої педагогічної освіти.

Мета статті - розкрити значення й особливості організації квазіпрофесійної діяльності майбутніх вихователів обдарованих дітей на практичних заняттях із педагогічних дисциплін у контексті їхньої підготовки до роботи з обдарованими дітьми.

Виклад основного матеріалу. На думку вчених, підготовка майбутніх дошкільних педагогів $є$ багатофакторною структурою, головне завдання якої полягає в набутті кожним студентом особистісного смислу діяльності, фрормуванні фрахової майстерності, постійно зростаючому інтересі до роботи з дітьми та їхніми батьками, а також у розвитку успішності в діяльності [11, с. 101]. Підготовку майбутніх дошкільних педагогів вихователів закладів дошкільної освіти до роботи з обдарованими дітьми визначаємо, з одного боку, як складову частину загальної підготовки.

Із другого боку, уважаємо ії окремою теоретико-методичною системою в контексті загальної підготовки. Обґрунтування їі елементів (мета, умови, етапи, форми і методи, результат) ускладнюється низкою чинників: неоднозначністю трактування самого френомену обдарованості та пояснення його природи, різними підходами до визначення структури обдарованості; дискусійністю понять «обдарована дитина» і «дитяча обдарованість»; відсутністю чіткого переліку ознак обдарованості; недостатньою розробленістю діагностичного інструментарію щодо виявлення проявів різних видів обдарованості в кожній віковій групі; наявністю протилежних позицій «усі діти потенційно обдаровані» - «обдаровані лише невелика частка осіб у віковий вибірці»; помилковістю ідентифікації дитини навченої / соціалізованої як обдарованої; неоднозначністю думок щодо того, 3 якого віку можна називати особистість обдарованою; побутуванням низки стереотипів у ставленні до обдарованих дітей, їхньому навчанні й вихованні; домінуванням думки, що всі обдаровані успішні; ігноруванням особливих потреб і проблем обдарованих дітей тощо.

Виходячи з позитивного досвіду підготовки фрахівців психолого-педагогічного профрілю до роботи з обдарованими дітьми, що склався в низці розвинених країн світу та Європи, таку роботу в нашій країні треба здійснювати комплексно, одночасно за декількома напрямами, серед яких такі:

1. Запровадження підготовки педагогів обдарованих дітей як окремої спеціалізації чи додаткової спеціальності. У контексті реформування вищої педагогічної освіти внесені зміни в перелік галузей знань і спеціальностей, за якими здійснюється підготовка здобувачів вищої освіти [12]. Так, освітні програми здобуття вищої освіти за спеціальностями 012 «Дошкільна освіта», 013 «Початкова освіта», 016 «Спеціальна освіта» передбачають підготовку із другої спеціальності або додаткової спеціалізації для здобуття відповідної профресійної педагогічної кваліфікації. Проте у визначеному списку спеціальностей / спеціалізацій поки що немає «педагога обдарованих дітей», уведення посади якого може бути перспективою для вдосконалення підготовки фрахівців для роботи з обдарованими дітьми.

Погоджуємося 3 тим, що в контексті впровадження інклюзивної освіти слушно надається додаткова психолого-педагогічна підтримка дітям з особливостями психофрізичного розвитку. Для їі здійснення у професійній педагогіці започаткована підготовка відповідних фрахівців, зокрема асистентів вихователя / учителя. Водночас уважаємо несправедливим, що досі у вітчизняних закладах освіти не введено посади спеціально підготовленого фрахівця для роботи з обдарованими дітьми як однією $з$ категорій особистостей з особливими освітніми потребами.

2. Включення у зміст освітніх програм підготовки майбутніх фрахівців психолого-педагогічного профрілю всіх спеціальностей навчальних дисциплін із вивчення науково-методичних основ роботи з обдарованими дітьми. За останніми даними, кількість осіб із проявами різних видів обдарованості може бути до 15-30\% від загальної вікової вибірки. Тобто приблизно кожна 5-та 3-тя дитина у групі / класі може бути потенційно обдарованою. Відповідно до цього, будь-який вихователь / учитель у дитячому колективі матиме талановитих особистостей, для розвитку загальних чи спеціальних здібностей яких йому потрібно мати відповідні знання й навички.

Підготовку майбутніх вихователів закладів дошкільної освіти до роботи 3 обдарованими 
дітьми необхідно спрямовувати на становлення студентів як суб'єктів / організаторів культурноосвітнього простору для розвитку дитячої обдарованості, вироблення в них фрасилятивної позиції та розвиток абнотивності як домінатної якості педагога обдарованих дітей. Педагоги обдарованих дітей у процесі освіти мають сорормувати готовність до:

- здійснення професійної діяльності 3 виявлення потенційно обдарованих дітей методом спостереження та використання діагностичних процедур у співпраці з іншими суб'єктами освітнього простору, зі створення умов для розкиття їхніх загальних і спеціальних здібностей на тлі всебічного розвитку, для досягнення успіху у відповідних видах діяльності шляхом актуалізації наявних психолого-педагогічних ресурсів і створення додаткових умов;

Надання психолого-педагогічної допомоги обдарованим дітям як особистостям з особливими освітніми потребами у процесі їхньої соціалізації та подолання соціально-психологічних проблем, зумовлених особливістю світосприйняття та поведінки; у налагодженні комунікації з однолітками й дорослими тощо.

Процес підготовки студентів до роботи з обдарованими дітьми передбачає оволодіння ними гуманістичними професійними цінностями, системою інтегрованих фрілософських і психолого-педагогічних знань про обдарованість, її види та прояви в дошкільному віці; комплексом спеціальних умінь, професійними та соціально зумовленими якостями, що утворюють відповідну компетентність. На лекційних заняттях із психолого-педагогічних дисциплін студенти здебільшого засвоюють систему знань у досліджуваному напрямі - із психології обдарованості, педагогічних засад теорії та технологій організації навчально-виховної роботи з дітьми дошкільного віку із проявами різних видів обдарованості. Вони є основою розвитку професійних навичок, обов'язковим елементом відповідної компетентності, але водночас недостатнім. Оскільки компетентність як здатність гнучко і творчо використовувати теоретичні положення у процесі розв'язання педагогічних завдань, пов'язаних із розвитком здібностей обдарованих дітей загалом і вирішенням їхніх соціально-психологічних проблем зокрема забезпечується професійними вміннями і якостями.

Одним зі шляхів досягнення такої мети в контексті підготовки майбутніх педагогів обдарованих дітей в освітньому процесі ЗВО є проведення практичних занять із педагогічних дисциплін. Загальні організаційні вимоги, методика проведення практичних занять розроблені й досить широко представлені в дидактиці вищої школи. Пропонується декілька варіантів структури такої форми навчання, проте викладач може внести свої корективи, удосконалити її відповідно до вимог компетентнісного підходу і контексту підготовки до роботи з обдарованими дітьми, залежно від специфіки й мети навчальної дисципліни тощо.

На думку Л. Зданевич, термін «практичні заняття» часто надто широко тлумачать, розуміючи під ним усі заняття, проведені під керівництвом викладача і спрямовані на поглиблення науково-теоретичних знань, оволодіння визначеними методами роботи за тією чи іншою дисципліною навчального плану. До практичних занять із майбутніми вихователями авторка відносить не тільки вправи на вирішення завдань за загальнонауковими дисциплінами, а й заняття із психолого-педагогічних дисциплін. На думку дослідниці, практичні заняття $€$ методом репродуктивного навчання, що забезпечує зв'язок теорії та практики, який сприяє виробленню в майбутніх вихователів умінь і навичок застосування знань, отриманих на лекціях і під час самостійної роботи [7, с. 164].

На основі загальних вимог до проведення практичних занять як однієї з фрорм організації освітнього процесу у вищій школі [8], власного досвіду роботи [6; 10] розроблено й апробовано в системі підготовки майбутніх вихователів закладів дошкільної освіти до роботи з обдарованими дітьми алгоритм їх проведення, який включає етапи, види і методи роботи.

Організація практичного заняття передусім включає підготовчу роботу студента на основі заздалегідь розробленої викладачем інструктивної картки, яка $є$ алгоритмом для його самостійної навчально-пізнавальної діяльності. В інструкції подано: цілі, яких повинен досягти студент під час участі у практичному занятті; список основної та додаткової літератури для вивчення теоретичних питань за темою заняття; перелік творчих завдань, рефлексивних вправ та їхній детальний методичний опис.

Завдання, які включені у структуру практичних занять, поділяються на обов'язкові для всіх студентів (вивчення літератури й підготовка відповідей на запитання, аналіз освітянських документів і праць класиків педагогіки, створення таблиць і моделей, розв'язання педагогічних завдань, підготовка до участі в ділових іграх, розроблення фррагментів занять, проведення мікродосліджень, створення проєктів тощо) і за вибором студента (написання есе і педагогічних казок, створення коміксів і колажів, розроблення рекомендацій тощо). Частину з них, здебільшого індивідуальних, майбутні вихователі цілком виконують у процесі самостійної роботи, презентуючи їх потім на практичному занятті. До деяких завдань, зазвичай групових, проводиться підготовча робота (студенти об'єднуються у групи, вибирають модератора й розподіляють обов'язки, продумують ідею реалізації, шукають необхідну інформацію, готують 
потрібні матеріали тощо). Завершення роботи над завданням відбувається безпосередньо на практичному занятті.

Більшість завдань мають пошуковий і творчий характер, розроблені на компетентнісній основі, що потребує використання знань у нестандартній пізнавальній чи педагогічній ситуації. Завдяки цьому їх виконання студентами сприятиме розвитку в останніх умінь і якостей, необхідних педагогу обдарованих дітей: критичного мислення, творчості, уміння генерувати ідеї, здатності до імпровізації, варіативності дій тощо.

Інструкцію студенти отримують заздалегідь (приблизно за 2-3 тижні до проведення практичного заняття), тому мають достатньо часу на підготовку складних комплексних завдань. Дотримуючись розробленого алгоритму та методичних рекомендацій викладача, студент організовує власну самостійну роботу з підготовки до практичного заняття, вибирає завдання, регулює її зміст і тривалість, виходячи зі своїх здібностей, інтересів і освітніх потреб.

Представимо методичні особливості організації практичного заняття з педагогічних дисциплін, структура якого містить такі складові частини:

1. Вступна частина (10 хв.): інтерактивна вправа для мотивації студентів, активізації їхньої діяльності, налаштування на роботу, самопрезентації; вступна бесіда з актуалізації опорних знань студентів, повідомленні теми, цілей заняття.

\section{2. Основна частина (60 хв.).}

\section{1. Теоретичний блок (30 хв.):}

- робота здебільшого репродуктивного характеру, яка має на меті обговорення, перевірку й узагальнення теоретичних положень із теми практичного заняття. Вона проводиться декількома способами (за вибором викладача): у малих групах (3-5 осіб) за технологією інтерактивного навчання; виконання студентами тестів; проголошення доповідей; проведення письмової роботи чи написання «педагогічного диктанту» тощо (20 хв.);

- робота проблемного / евристичного характеру 3 розв'язання суперечних питань, аналізу дискусійних думок, що сприятиме розвитку критичного мислення, виробленню педагогічної позиції студента, засвоєнню демократичних цінностей. Одним зі способів її проведення є виконання однієї 3 фрілософських вправ за методикою Хельског, Хансен Ґюро (А. Опитування. В. Відображення досвіду. C. Заяви, аргументи та причини. D. Критерії та погляди. Е. Тлумачення та розуміння. F. Емоції та ставлення. G. Етика моральні дії. Н. Людина в контексті пропонованого питання. І. Існування і просвітління) [16]. За вибором викладача на цьому етапі також можна провести фрронтальну евристичну бесіду, дискусію, мозковий штурм, вправу «Сім капелюшків» Едварда де Боно [2], застосувати інші інтерактивні / проблемні методи (10 хв.).
2.2. Креативно-практичний блок (30 хв.):

- робота в парах або малих групах (3-5 осіб) із завершення виконання спільного творчого завдання / врегулювання педагогічної ситуації / проведення навчально-педагогічної гри 3 метою вироблення вмінь використовувати теоретичні знання в умовах квазіпрофессійної діяльності (20 хв.);

- презентація творчих завдань (таблиці, есе, моделі тощо), виконаних за бажанням студента під час самостійної підготовчої роботи (10 хв.).

\section{3. Заключна частина (10 хв.):}

- інтерактивна рефрлексивна вправа 3 метою аналізу та самоаналізу активності студентів на практичному занятті, рівня їхньої задоволеності своєю участю і досягненнями (5 хв.);

- рефлексивна бесіда, спрямована на оцінку та самооцінку рівня засвоєних знань із темі практичного заняття й якості виконаних творчих завдань, виставлення викладачем балів за участь студентів у практичному занятті (5 хв.).

- Основою проведення практичних занять $€$ організація квазіпрофресійної діяльності здобувачів вищої освіти як одного з видів контекстного навчання, сутність яких обґрунтовано у працях А. Вербицького [2]. Така діяльність тлумачиться як орорма організації навчально-пізнавальної діяльності студентів у контекстному навчанні, що об'єднує в собі ознаки навчальної та майбутньої професійної діяльності. Суть її полягає в тому, що за допомогою мови навчальної інформації у ЗВО (під час практичних занять, позааудиторної роботи із психолого-педагогічних дисциплін, у наукових гуртках тощо) моделюються умови, зміст і динаміка виробничого процесу (система освіти - сорера духовного виробництва), взаємини зайнятих у ньому людей. Саме квазіпрофресійна діяльність здобувачів вищої освіти у спеціально створених умовах (імітація / відтворення реальних педагогічних ситуацій) сприяє виробленню в них комплексу вмінь, особистісних і професійних якостей, необхідних для успішного здійснення майбутньої професійної діяльності. Системна й алгоритмічно організована викладачем квазіпрофесійна діяльність студентів на практичних заняттях сприятиме виробленню вмінь, необхідних для роботи з обдарованими дітьми, зокрема таких:

- творчо використовувати психолого-педагогічні знання 3 теорії обдарованості в умовах, наближених до реального освітнього процесу;

- аналізувати педагогічні завдання та ситуації, пов'язані з розвитком і вихованням обдарованих дітей, шукати альтернативні варіанти їх вирішення;

- швидко орієнтуватися й адаптуватися в нових педагогічних ситуаціях, мобільно реагувати на них і оперативно вирішувати проблеми; 
- моделювати індивідуальну траєкторію розвитку дитини із проявами обдарованості та розробляти програму її створення;

- підбирати інноваційні методи, прийоми розвитку здібностей і обдарувань дітей, інтерактивні технології для підвищення суб'єктності самої обдарованої дитини у процесі розгортання її творчого потенціалу;

- використовувати доступні та шукати додаткові ресурси (матеріальні, срінансові, інтелектуальні, методичні тощо) у процесі розв'язання педагогічних завдань;

- творчо й оригінально виконувати індивідуальні завдання, проєкти, презентувати результати своєї діяльності у процесі підготовки до роботи 3 обдарованими дітьми в умовах ЗВО;

- взаємодіяти з одногрупниками, студентами інших курсів і спеціальностей, викладачами, педагогами-практиками й іншими учасниками ділової гри у процесі вирішення проблеми, виконання завдань і доручень;

- здійснювати самодіагностику рівня розвитку творчого потенціалу, сорормованості професійнопедагогічних якостей на всіх етапах професійної освіти та в педагогічній діяльності;

- оцінювати й аналізувати результативність проведеної розвитково-виховної роботи з обдарованими дітьми, ефективність використаних педагогічних технологій і методів;

- проводити педагогічну рефрлексію й оцінювати рівень підготовленості до роботи з обдарованими дітьми;

- моделювати й реалізовувати програму власного профресійного й індивідуального вдосконалення [5].

У працях низки дослідників знаходимо методичний опис різних методів, які ефективно апробовані під час проведення практичних занять із педагогічних дисциплін: ділових ігор [4], бліц-гри [7], моделювання і врегулювання педагогічних ситуацій [8], соціоігрових методів [9] тощо. Найбільш повно квазіпрофесійна діяльність розкривається в діловій грі, яка відтворює предметний, соціальний і психологічний зміст реальної професійної діяльності фрахівця, задає цілісний контекст його діяльності [3, с. 72]. Під час підготовки майбутніх вихователів ЗДО до роботи з обдарованими дітьми розроблені й організовані такі ділові ігри: педагогічна рада у ЗДО «Обдарованість у дошкільному віці: чи можна виявити її прояви?», творчий педагогічний кастинг «Сьогодні креативний студент, завтра - майстер «фрабрики творчих індивідуальностей»»; «педагогічний суд» над нетворчим педагогом «Руйнівник дитячої креативності»; співбесіда на заміщення вакансії педагога в інноваційному закладі освіти для обдарованих дітей «Шукаємо абнотивного педагога для обдарованих дітей»; телепередача «Прогноз «педагогічної погоди» в освітньому закладі для обдарованих дітей» тощо.
Висновки. На сучасному етапі розвитку вищої педагогічної освіти ії̈ важливим напрямом уважаємо здійснення підготовки майбутніх вихователів до роботи з обдарованими дітьми. Педагог обдарованих дітей має володіти низкою специфічних якостей, для фрормування яких доречно використовувати можливості квазіпрофесійної діяльності. Вона організовується на практичних заняттях із педагогічних дисциплін, що дозволяє забезпечити студентам можливість інтеріоризації здобутих знань у педагогічні цінності, вироблення вмінь і розвитку педагогічних здібностей, необхідних для роботи з обдарованими дітьми.

\section{БІБЛІОГРАФІЧНИЙ СПИСОК:}

1. Бєлєнька Г. Підготовка фрахівців для дошкільної галузі: стратегія змін. Молодий вчений. 2017. № 3.2 (43.2). С. 1-3.

2. Боно Э. Шесть шляп мышления. Пер. с англ. Минск : Попурри, 2006. 208 с.

3. Вербицкий А. Активное обучение в высшей школе: контекстный подход. Москва, 1991. 207 с.

4. Развитие субъектности будущих педагогов в контексте подготовки к работе с одаренными детьми / Е. Демченко и др. Society, Integration, Education: Proceedings of the International Scientific Conference, May $25^{\text {th }}-26^{\text {th }}, 2018$. Rezekne : Rezekne Academy of Technologies, 2018. P. 507-519.

5. Демченко Е., Кепуле И. Формирование креативной компетентности будущих педагогов в контексте подготовки к работе с одаренными детьми. Молодий вчений. 2018. № 5.2 (57.2). С. 28-35.

6. Демченко О. Практикум 3 історії педагогіки : навчально-методичний посібник для викладачів історії педагогіки, на допомогу студентам педагогічних ВНЗ під час самостійного вивчення теоретичних основ, підготовки до семінарських і практичних занять. Київ : Видавничий дім «Слово», 2012. 432 с.

7. Зданевич Л. Бліц-гра як фрорма проведення практичного заняття 3 майбутніми вихователями дошкільних навчальних закладів. Педагогіка фрормування творчої особистості у вищій і загальноосвітній школах. 2013. Вип. 30 (83). С. 163-168. URL: http://www / Pfto_2013_30_28\%20(1).pdf.

8. Каплінський В., Лазаренко Н. Методика проведення практичних занять у вищій школі як важлива умова фрормування методичної компетентності студентів. Наукові записки ВДПУ ім. М. Коцюбинського. Педагогіка і психологія. Вип. 49. Вінниця : ТОВ «Нілан ЛТД», 2017. С. 59-66.

9. Крутій К., Пастюк О. Шляхи знайомства студентів бакалавріату з основами соціо-ігрової педагогіки. Забезпечення якісної підготовки майбутніх бакалаврів дошкільної освіти в процесі використання сучасних технологій : збірник матеріалів Міжнародної (заочної) науково-практичної конференції. Хмельницький : ХГПА, 2015. С. 121-126.

10. Міщик Л., Демченко О. Вступ до спеціальності «Соціальна педагогіка» : навчальний посібник. Київ : Видавничий дім «Слово», 2013. 328 с.

11. Підготовка вихователя до розвитку особистості дитини в дошкільному віці / Г. Бєлєнька та ін. ; 
за заг. ред. І. Загарницької. Київ : Вид-во НПУ імені М.П. Драгоманова, 2009. 310 с.

12. Про затвердження переліку галузей знань і спеціальностей, за якими здійснюється підготовка здобувачів вищої освіти : постанова Кабінету Міністрів України від 29 квітня 2015 р. № 266. URL: http://parusconsultant. $\mathrm{com} /$ ?doc $=09 \mathrm{~K} 505 \mathrm{DBF} 2 \& \mathrm{abz}=\mathrm{GYZHX}$.

13. Руденко Л. Особливості підготовки майбутніх магістрів дошкільної освіти до розвитку дитячої обдарованості. Проблеми діагностики та проєктування розвитку обдарованості дошкільників. Київ : Інститут обдарованої дитини, 2014. С. 197-201.
14. Савченко Р. Теорія і методика фрормування музично-педагогічної компетентності майбутніх вихователів та музичних керівників дошкільних навчальних закладів : автореф. дис. ... докт. пед. наук: 13.00.02. Київ, 2014. 43 с.

15. Ушатикова И. Подготовка будущих учителей к работе с одаренными школьниками : автореф. дис. ... канд. пед. наук: 13.00.01. Казань, 2006. 22 с.

16. Helskog, Guro Hansen, 2018. Envisioning the Dialogs way towards wisdom. Understanding oneself and each other: conference proceedings after the $14^{\text {th }}$ Conference on philosophical practice in Bern 2017 / Detlef Staude et al. London : Cambridge Scholar. 